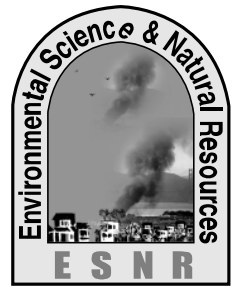

J. Environ. Sci. \& Natural Resources, 5(2): 205 - 207, 2012

ISSN 1999-7361

\title{
Effect of Presprouting of Seeds on Field Duration of Short and Long Duration Potato Varieties in Haor Ecosystem \\ M. M. Karim ${ }^{1}$, M. S. U. Bhuiya ${ }^{2}$, B. C. Das ${ }^{1}$ and S. M. A. Hossain ${ }^{1}$ \\ ${ }^{1}$ LIFCHASA project, Department of Agronomy, ${ }^{2}$ Department of Agronomy \\ Bangladesh Agricultural University, Mymensingh
}

\begin{abstract}
A field experiment was conducted at the farmers' field of Livelihood Improvement of Farming Community in Haor Area through System Approach Project site Purbo Tethulia, Mohangonj, Netrakona during the Rabi Season of 2011-2012 to shorten the field duration of potato through seed pre-sprouting technique and to find out the suitable potato variety for cultivation in Dingaputa haor area without affecting the cultivation period of boro rice. Diamont and one local variety Challisha were taken for the study. Pre-sprouting duration of Diamont was 10, 20, 30 and 40 days with un-sprouted Diamont and Challisha. In the study unsprouted

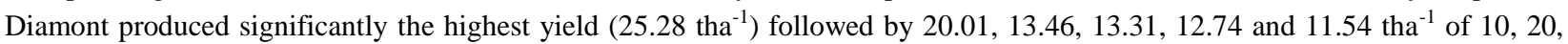
30, 40 days pre-spouted Diamont and un-sprouted Challisha, respectively. The lowest field duration of the crop was 41 days of 30 and 40 days pre-spouted Diamont. The highest gross margin of Tk.165960 ha ${ }^{-1}$ was observed from the unsprouted Diamont potato against the variable cost of Tk.137400 ha ${ }^{-1}$ incurred. The performance of Challisha was also appreciated by the farmers for its quality and low cost of production. Unsprouted Diamont potato also ranked the top most position in terms of benefit cost ratio of 2.21
\end{abstract}

Keywords:Diamont, Challisha, Presprouting, Field duration, Yield, Gross Margin, Gross Return

\section{Introduction}

Haor is a bowl-shaped depression of typical low land area within the estuarine flood plain of the Surma, Kushiyara, Meghna, Dhenu and Ghorautre rivers. The haors of Bangladesh cover the districts of Kishoreganj (eastern part), Netrokona, Sunamganj, Habiganj, Moulabibazar and part of Sylhet and Brahmanbaria (Haor Task Force Report, 1985). The haor area extends as many as 43 upazilas of the aforesaid districts. The area of the haor is about 932793 hectares (Hossain and Bhuiya, 2011). The haors undergo deep flooding (5-10 m) from late May to October while it looks like a sea. There is only one cropping season in haor i.e. the Rabi, when Boro rice, potato, groundnut, sweet potato, mustard, pulse, etc. are grown. The haor is highly potential area for rice production and fishery resources. It contributes over $10 \%$ to the national production of rice. In spite of its high potentiality the haor people suffer from chronic food and nutritional insecurity due to chronic poverty and natural disasters like flash flood, hailstorm and insect infestation. Sometimes in some years the crops of the haor areas are affected by natural calamities as mentioned. From a survey conducted in Purbo Tethulia village of Dingaputa haor in Netrokona District, it has been found that $86 \%$ of the cultivated land is occupied with Boro rice.

\section{Materials and Methods}

A field experiment was carried out at the farmers' field of Livelihood Improvement of Farming Community in Haor Area through System Approach Project site Purbo Tethulia, Mohangonj, Netrakona during the Rabi Season of 2011-2012 to shorten the field duration of potato through seed presprouting technique and to find out the suitable potato variety for cultivation in Dingaputa haor area without affecting the cultivation period of boro rice. The experiment site belongs to the AEZ \# 21 having high organic matter content (2.27\%) and low $\mathrm{pH}$ (5.61). The experiment was set up following randomized complete block design with three replications. Diamont and one local variety Challisha were taken for the study. Presprouting duration of Diamont was 10, 20, 30 and 40 days with one unsprouted Diamont and Challisha. Seeds of potato cv. Challisha were collected from local market of Kaltapara, Gouripur, Mymensingh and Diamont from BADC. Diamont potato seeds were set for sprouting in four different dates viz., 25 September, 5 October, 15 October and 25 October 2011 in polybags $(15.24 \mathrm{~cm} \times 10.16 \mathrm{~cm})$ filled with equal mixture of well decomposed compost and soil. Land was prepared during the end of October 2011. Fertilizers were applied at the rates of $276,185,276$ and $15,10 \mathrm{~kg} \mathrm{ha}^{-1}$ as urea, TSP, 
MoP, zinc sulphate and boric acid, respectively. Total TSP, MoP, zinc sulphate, boric acid and a half of the urea were applied during the final land preparation and the rest half of urea was top dressed at 30 days after seed sowing. Diamont seeds with having presprouting ages of 40,30, 20, 10 days were planted in four plots and unsprouted Diamont and Challisha seeds were sown in two plots on 4 November 2011. Spacing of $60 \mathrm{~cm} \times 25 \mathrm{~cm}$ for Diamont and $30 \mathrm{~cm} \times$ $10 \mathrm{~cm}$ for Challisha was maintained. The unit plot size was $4 \mathrm{~m} \times 2.5 \mathrm{~m}$. Irrigation and weeding were done as and when necessary. To control late blight, Ridomil gold was applied @ $1 \mathrm{kgha}^{-1}$ and Durseban for cutworm @ $7.50 \mathrm{ml} \mathrm{ha}^{-1}$. Harvesting was done from 22 December, 2011 to 12 January 2012. Plot-wise yield was recorded and finally converted to $\mathrm{tha}^{-1}$.

\section{Results and Discussion}

The main objective of the experiment was to shorten field duration of Diamont potato variety in order to fit it in Potato-Boro rice cropping pattern. In fact Diamont unsprouted and Challisha matured in 67 days i.e. Diamont is well fitted in the said cropping pattern without pre-sprouting treatment. In fact only for early harvest pre-sprouting treatment could be done (Table 1). The highest yield (25.28 t ha ${ }^{-1}$ ) was obtained from unsprouted Diamont potato. The highest gross margin of Tk.165960 ha ${ }^{-1}$ obtained from the unsprouted Diamont potato against the variable cost of Tk.137400 ha ${ }^{-1}$ incurred. The performance of Challisha was also appreciated by the farmers for its quality and low cost of production. Un-sprouted Diamont potato also ranked the top most position in terms of benefit cost ratio of 2.21. Twenty days sprouted age Diamont potato emerged as the next most profitable in terms of gross margin. The performance of Challisha was also appreciated by the farmers for its quality and low cost of production.

Table 1 Effect of duration of presprouted seed on agro-economic performance of potato, Purbo Tethulia, 2011-12

\begin{tabular}{|c|c|c|c|c|c|c|c|c|}
\hline \multirow[t]{2}{*}{ Variety } & \multirow{2}{*}{$\begin{array}{l}\text { Age of pre- } \\
\text { sprouted seed } \\
\text { (Day) }\end{array}$} & \multirow{2}{*}{$\begin{array}{l}\text { Date of } \\
\text { harvest }\end{array}$} & \multirow{2}{*}{$\begin{array}{c}\text { Field } \\
\text { duration } \\
\text { (Day) }\end{array}$} & \multirow{2}{*}{$\begin{array}{c}\text { Yield } \\
\left(\mathrm{t} \mathrm{ha}^{-1}\right)\end{array}$} & \multicolumn{3}{|c|}{ Economic indicator } & \multirow{2}{*}{$\begin{array}{l}\text { Benefit cost ratio } \\
\text { (Undiscounted) }\end{array}$} \\
\hline & & & & & $\begin{array}{c}\text { Total } \\
\text { variable } \\
\text { cost } \\
\left(\mathrm{Tk} \mathrm{ha}^{-1}\right)\end{array}$ & $\begin{array}{c}\text { Gross } \\
\text { return } \\
\left(\mathrm{Tk} \mathrm{ha}^{-1}\right)\end{array}$ & $\begin{array}{c}\text { Gross } \\
\text { margin } \\
\left(\mathrm{Tk} \mathrm{ha}^{-1}\right)\end{array}$ & \\
\hline Diamont & 40 & 15.12 .11 & 41 & $13.31 \mathrm{c}$ & 137400 & 239580 & 102180 & 1.74 \\
\hline Diamont & 30 & 15.12 .11 & 41 & $12.74 \mathrm{c}$ & 137400 & 229320 & 91920 & 1.67 \\
\hline Diamont & 20 & 22.12 .11 & 48 & $20.01 b$ & 137400 & 300150 & 162750 & 2.18 \\
\hline Diamont & 10 & 22.12 .11 & 48 & $13.46 \mathrm{c}$ & 137400 & 201900 & 64500 & 1.46 \\
\hline Diamont & Unsprouted & 12.01 .12 & 67 & $25.28 \mathrm{a}$ & 137400 & 303360 & 165960 & 2.21 \\
\hline Challisha & Unsprouted & 12.01 .12 & 67 & $11.54 \mathrm{c}$ & 129900 & 230800 & 100900 & 1.78 \\
\hline LSD (0.05) & & & & 3.132 & & & & \\
\hline $\mathrm{CV}(\%)$ & & & & 11.32 & & & & \\
\hline
\end{tabular}

Sale price of Diamont on 15.12.11- Tk.18 kg-1, on 22.12.11- Tk.15 kg-1 , on 12.01.12- Tk.12 kg ${ }^{-1}$ and Challisha-Tk. $20 \mathrm{~kg}^{-1}$

\section{Conclusion}

Farmers showed their keen interest in potato cultivation in boro rice field prior to boro rice transplanting and especially on pre-sprouting technique of potato seed for early maturity for Diamont and quality and low cost of production for Challisha.

\section{Acknowledgement}

The authors acknowledge the financial support of BARC funded for Livelihood Improvement of Farming Community in Haor Area through System Approach project for the study. The LIFCHASA project acknowledges the participatory farmers for their spontaneous cooperation. 


\section{References}

Hossain, S. M. A.; Alam, A. B. M. M. and Salam, M. U. 1996a. Evaluation of farming systems approach through farmers' participatory method. In: Fact Searching and Intervention 1991-1995. Part I. Farming Systems and Environmental Studies, Bangladesh Agril. Univ., Mymensingh. pp. 76-87.

Hossain, S. M. A.; Alam, A. B. M. M.; Kashem, M. A. and Bari, M. N. 1996. Effects of agricultural activities on environment. In: Fact Searching and Intervention 19911995. Part I. Farming Systems and Environmental Studies, Bangladesh Agril. Univ., Mymensingh. pp. 175-210.

Hossain, S. M. A.; Alam, A. B. M. M. and Salam, M. U. 1996. Effects of FSES activities on farm resources, productivity, employment generation and environment. In: Fact Searching and Intervention 1991-1995. Part III. Farming Systems and Environmental Studies, Bangladesh Agril. Univ., Mymensingh. pp. 46-65.

Hossain, S. M. A. and Kashem, M. A. 1996. FSRextension demonstration trial on two varieties of potato. In: Fact Searching and Intervention 1991-1995. Part II. Farming Systems-and Environmental Studies, Bangladesh Agril. Univ., Mymensingh. pp. 153-154.
Islam, M. S. and Khan, K. A. 1996. Disposal pattern of major agricultural commodities by the farmers. In: Fact Searching and Intervention 1991-1995. Part II. Farming Systems and Environmental Studies, Bangladesh Agril. Univ., Mymensingh. pp. 541-547.

LIFCHASA (Livelihood Improvement of Farming Community in Haor Area through System Approach). 2010. Bench Mark Survey Report, LIFCHASA.

Salam, M. U.; Hossain, S. M. A. and Alam, A. B. M. M. 1996. Scenarios of farm environment of Bangladesh and the need for quality assessment. In: Fact Searching and Intervention 1991-1995. Part I. Farming Systems and Environmental Studies, Bangladesh Agril. Univ., Mymensingh. pp. 152-174.

World Bank, 1992. Bangladesh Food Policy Review: Adjusting to the Green Revolution. Industry and Finance Division, South Asia Region, World Bank, Washington D.C. 